\title{
Antimicrobial and Antioxidant Activities of Different Spice Extracts
}

\author{
Gulten Okmen ${ }^{1 *}$, Kutbettin Arslan ${ }^{2}$, Ridvan Tekin $^{3}$, Irem Camur ${ }^{4}$, Sabri Gorda ${ }^{5}$ \\ ${ }^{1 *}$ Mugla Sitki Kocman University, Faculty of Science, Department of Biology, Mugla, TURKEY (ORCID: 0000-0003-3207-6715) gultenokmen@ gmail.com \\ ${ }^{2}$ Mugla Sitki Kocman University, Faculty of Science, Department of Biology, Mugla, TURKEY (ORCID: 0000-0002-7724-7875) kutbettinarslan@gmail.com \\ ${ }_{3}^{3}$ Mugla Sitki Kocman University, Faculty of Science, Department of Biology, Mugla, TURKEY (ORCID: 0000-0001-7282-4613) rdvn.tkn21@gmail.com \\ ${ }^{4}$ Mugla Sitki Kocman University, Faculty of Science, Department of Biology, Mugla, TURKEY (ORCID: 0000-0002-9531-5296) iremmcamurrr@gmail.com \\ ${ }^{5}$ Mugla Sitki Kocman University, Faculty of Science, Department of Biology, Mugla, TURKEY (ORCID: 0000-0002-9531-5296) sabrigorda8@gmail.com
}

(First received December 2020 and in final form January 2021)

(DOI: 10.31590/ejosat.848958)

ATIF/REFERENCE: Gulten, O., Arslan, K., Tekin, R., Camur, I., \& Gorda, S. (2021). Antimicrobial and Antioxidant Activities of Different Spice Extracts. European Journal of Science and Technology, (22), 421-429.

\begin{abstract}
Up to day, very little work has been done on the antimicrobial activity of spices extracts against food pathogens. Additionally, there is very little information about the antioxidant activities of spices. The aim of this work was to investigate the antimicrobial effects of spices extracts against food pathogens, and its non-enzymatic antioxidant potentials. The plants have been provided from C2 region of Mugla and local herbalists. Antimicrobial activities of plants were evaluated using disc diffusion method. The extracts showed maximum inhibition zone against various microorganisms, and the zone was $8 \mathrm{~mm}$. Candida albicans and Listeria monocytogenes showed the lowest sensitivity to different extracts $(3250 \mu \mathrm{g} / \mathrm{ml})$. In addition, the extracts were tested against the DPPH [2,2-Diphenyl1-picrylhydrazyl] free-radical for antioxidant activity. A lot of extracts were displayed a high antioxidant activity. The highest antioxidant activity was determined on Nigella sativa (84\%). In this study determined that the spices extracts have antimicrobial and antioxidant properties.
\end{abstract}

Keywords: Coriandrum, Mentha, Ribes, Nigella, Thymus, Origanum, Crocus, food pathogen, biological activity

\section{Farklı Baharat Özütlerinin Antimikrobiyal ve Antioksidan Aktivitelerinin Saptanması}

Öz

Günümüze kadar, gıda patojenlerine karşı baharat özütlerinin antimikrobiyel aktivitesi üzerine çok az çalışma yapılmıştır. İlaveten, baharatların antioksidan aktiviteleri hakkında çok az bilgi vardır. Bu çalışmanın amacı, gıda patojenlerine karşı baharat özütlerinin antimikrobiyel etkilerini ve bunların enzimatik olmayan antioksidan potensiyellerini araştırmaktır. Bitkiler, Muğla' nın C2 bölgesinden ve yerel aktarlardan sağlanmıştır. Bitkilerin antimikrobiyel aktiviteleri disk difüzyon metodu kullanılarak ölçülmüştür. Buna ek olarak, özütler antioksidan aktivite için 2,2-Difenil-1-pikrilhidrazil (DPPH•) serbest radikaline karşı test edilmiştir. Özütler, çeşitli mikroorganizmalara karşı maksimum inhibisyon zonu göstermiştir ve bu zon 8 mm'dir. Candida albicans ve Listeria monocytogenes, farklı bitki özütlerine en düşük duyarlılığı göstermiştir (3250 $\mu \mathrm{g} / \mathrm{ml})$. Özütlerin birçoğu yüksek antioksidan aktivite sergilemiştir. En yüksek antioksidan aktivite Nigella sativa' da saptanmıştır (\%84). Bu çalışmada, baharat özütlerinin antimikrobiyal ve antioksidan özelliklere sahip olduğu saptanmıştır.

Anahtar Kelimeler: Coriandrum, Mentha, Ribes, Nigella, Thymus, Origanum, Crocus, gida patojeni, biyolojik aktivite

* Corresponding Author: gultenokmen@gmail.com 


\section{Introduction}

Foodborne diseases emerge as an increasingly serious public health problem all over the world. The control of pathogens can significantly reduce foodborne disease outbreaks (Kiran et al., 2008). In 2005, it was reported that 1.8 million people died from diarrheal diseases (WHO, 2005), this is substantially due to contaminated food and drinking water. Antimicrobial resistance is a particular problem for bacterial pathogens in the food chain. For more than 50 years, the use of antimicrobial agents in both human and veterinary has been an important factor in the treatment of infectious diseases, but as a result, the development of antimicrobial resistance has increased and become widespread. The consequences of this resistance in terms of public health are a failure in treatment, long-lasting illnesses, the progression of systemic infections, an increased number of hospitalizations, and increased mortality (WHO, 2008).

Medicinal plants are very powerful and effective sources of drugs, they are also used for medicinal purposes in different countries (Srivastava et al., 1996). Nowadays, the importance of using spices and extracts for food preservation has increased because consumers are directed to foods with minimal processing and no chemical additives. It is known that extending the shelf life of perishable foods with natural additives is of great importance. In parallel with the emergence of various harms of chemical additives on human health and various studies that demonstrate the benefits of spice ingredients, the use of spices in foods has gained more importance (Üner et al., 2000).

Crocus sativus (Safran), one of the oldest known spices, is from the family Iridaceae, it is a $20-30 \mathrm{~cm}$ tall Crocus plant that blooms in autumn, and is a spice obtained from this plant. Saffron is used among people as a sedative and pain medication in gastrointestinal diseases. It is also used in the treatment of diseases such as heart palpitations, shortness of breath, gout, impotence, anemia (Rios, et al., 1996; Baytop, 1999). Modern pharmacological studies show that saffron extracts and their active components have anticonvulsant (Hosseinzadeh and Khosravan, 2002a), antidepressant (Hosseinzadeh, et al., 2004), anti-inflammatory (Hosseinzadeh and Younesi, 2002b), and antitumor effects (Escribano et al., 1996). Moreover, saffron has antioxidant (Verma, 1998; Martinez, et al., 2001) anti-viral, diuretic, hypoglycemic and hypocholesterolemic activity (Wintherhalter, 2000).

The common feature of Thymus serpyllum (Kekik) species mostly used in our country is that they contain essential oil and the main components of these essential oils are thymol and carvacrol. It has antiseptic, balsamic, anticonvulsant, and antibiotic properties. It is used in the treatment of pertussis, hookworms, mouthwash, gums (Gürsoy and Gürsoy, 2004). It is good for the stomach and also has soothing, worm-lowering, blood circulating stimulating effects and is used as a spice in kitchens (Baytop, 1999).

Coriandrum sativum L. (Kişniş) is from the family Umbelliferae (Baytop, 1999; Akgül, 1993). It is an annual, herbaceous, $20-60 \mathrm{~cm}$ tall plant. The spice contains essential oil, tannins, resins, and sugars. It is good for the stomach and has a degassing effect (Baytop, 1999). It has been reported in folk medicine to relieve headaches, toothaches, finger pains, dizziness, throat (pharyngitis), and tongue swelling, to strengthen the heart and stomach, to treat hemorrhoids and bloody diarrhea, urinary tract infections, and hives and thrush (Pamuk, 1998).

Nigella sativa (Çörek otu) is a family of Ranunculaceae and is known as black seed, black cumin, or a cornucopia (fertility grain) in our country, which is very rich in plant diversity. The structure of the unsaturated oil includes oleic acid, linoleic acid, eicozadienoic, arachidonic acid, and linolenic acid, while the saturated fatty acids include myristic acid, palmitic acid, and stearic acid. Studies conducted on Nigella sativa seeds and their components have shown anti-cancerogenic (Kaseb et al., 2007), anti-tumoral (Badary, 1999), anti-ulcerogenic (Kanter et al., 2005), antibacterial (Halawani, 2009), anti-inflammatory and analgesic (Abdel-Fattah et al., 2000), antioxidant (Badary et al. , 2000), it has hypoglycemic effects (Badary et al., 1998; Badary 1999). The essential bioactive component of black seed essential oils, thymoquinone has been used as an antioxidant, antiinflammatory, and antineoplastic drug for a long time (Trang et al., 1993; Hosseinzadeh et al., 2004).

Mentha (Nane), a genus of the Labiatae (Ballibabagiller) family, has about 7 species in Anatolia. Of these, the smell of Mentha piperita L. is special and strong, and the taste is cooling. It is used to relieve nausea, degassing, and odor. The essential oil obtained by water vapor distillation from the flowering and leafy branches of the Mentha piperita species is called peppermint. This essential oil is used for a mild antiseptic, refreshing, fragrance, and nausea.

Ribes nigrum (Kuş üzümü, siyah frenk üzümü) is a deciduous and aromatic shrub that can develop up to $2 \mathrm{~m}$ tall (Rehder, 1986). Plant buds are a rich source of aroma-volatile compounds, the majority of which consisted of oxygenated fractions of hydrocarbons and terpenes (Dvaranauskaite et al., 2009). As a result of studies on buds, total phenolics, and antioxidants are extracted and then used in most applications (Tabart et al., 2006; 2007; 2011; Dvaranauskaite et al., 2008). Traditionally, plant leaves are used in folk medicine in Europe to treat rheumatism, arthritis, and respiratory problems (Stević et al., 2010). The leaves have been reported to show antiinflammatory activity in various trials (Declume, 1989; Garbacki et al., 2005). Besides, the composition and antimicrobial activity of essential oils of the plant buds and leaves have been reported in recent years (Opera et al., 2008; Stević et al., 2010).

Origanum majorana L. (Mercan köşkü) is known as the Cyprus medical endemic plant and "Sampsishia". Johannes et al. (2002) reported the essential oils of this plant. Essential oils are used for sauces, seasonings, and other products (deVincenzi et al., 1997). The plant used in India as a diuretic, anti-asthma, and anti-paralytic (Yadava and Khare, 1995), and also is a common salad plant (Picton et al., 2000). Also, tea is made from herbal vinegar and leaves (Facciola et al., 1998). Used in cancer treatment (Leung et al., 2003), Stefanakis et al. (2013) reported that essential oil extracted from various types of Origanum can be used for the disinfection of rotifers, Abdel Massih et al. (2010) reported that it has antiproliferative and antioxidant activity. Koidis et al. (1996) reported their inhibitory effect on the development of Campylobacter jejuni in their study with 4 spices including marjoram.

The World Health Organization (WHO) reports that medicinal plants may be the top source for providing the 
diversity of drugs, however, the impact and safety of such plants should be better understood (Nascimento et al., 2000). Although there are studies on the biological activity of spices, Turkey's Mugla at widely grown and used spices, there are no studies on antimicrobial activity and antioxidant activity against food pathogens. The goal of this study is to investigate the biological activities of different spices against food pathogens and to contribute to the lack of information on these activities in the literature.

\section{Material and Method}

\subsection{Plant materials}

Spice samples, which are research materials, were obtained from Muğla (C2) region and local akthars. There are 7 spices used in the study; Mentha piperita (mint), Ribes nigrum (currant), Nigella sativa (black seed), Origanum majorana (marjoram), Thymus serpyllum (thyme), Coriandrum sativum (coriander), Crocus sativus (saffron). Spice materials were identified by Dr. Olcay Ceylan and samples are stored in the herbarium of the Department of Biology, Mugla Sitk1 Kocman University, Turkey. The identification of plant materials was made according to Davis (1978).

\subsection{Organisms}

The four food pathogens were used in the study, 3 of them are bacteria and one is yeast. These; Escherichia coli ATCC11229, Salmonella Typhimurium RSKK19, and Listeria monocytogenes ATCC7644 are bacteria, and the yeast is Candida albicans RSKK02029. Bacterial cultures were developed at Mueller-Hinton Broth (Merck) environment at $37^{\circ} \mathrm{C}$ for 24 hours, and yeast at Sabouraud Dextrose Agar medium (at $30^{\circ} \mathrm{C}$ for 24 hours). Microorganisms were obtained from ATCC (American Type Culture Collection, USA), and RSKK (Refik Saydam National Type Culture Collection, Turkey).

\subsection{Preparation of spice materials}

The samples were washed 2-3 times in flowing water and once in sterile distilled water. The spices are dried in the air and powdered in the slicer. All materials were held on at room temperature until sample preparation, then stored at $4^{\circ} \mathrm{C}$ till needed for analysis.

\subsection{Preparation of spice extracts}

Air-dried and powdered samples were extracted with methanol and ethanol using the Soxhlet apparatus. The essential extracts of spices with essential oil content were taking into the Clevenger apparatus and essential oils were obtained. After the extracts in organic solvents were evaporated, each of them was preserved under refrigerator conditions until used in small sterile opaque bottles in its own solvent.

\subsection{The Cultivation of organisms}

There are 3 bacteria to be used in the study, Escherichia coli ATCC11229, Salmonella Typhimurium RSKK19, and Listeria monocytogenes ATCC7644. However the yeast agent is a 1 and that is Candida albicans RSKK02029. Microorganisms were produced by incubation at their own temperatures for 24 hours in Mueller-Hinton Broth (MHB, Merck) medium. The active cultures were used for all trials. Turbidite of all bacterial cultures was set to 0.5 McFarland.

\subsection{Determination of Antimicrobial Activity}

Antimicrobial activity studies were conducted using KirbyBauer (1966) disc diffusion method. The methanol, ethanol, and aqueous extracts of spice samples $(150 \mathrm{mg} / \mathrm{ml})$ were tested by disk diffusion method, cultures were incubated on MuellerHinton Agar plates (MHA, Merck) for 24 hours at their own temperature. Turbidity of bacterial cultures is set at $0.5 \mathrm{Mc}$ Farland. After the incubation, the inhibition zones formed were recorded in $\mathrm{mm}$.

\subsection{Determination of Minimum Inhibitor}

\section{Concentration (MIC)}

In this study, the values of minimum inhibitory concentration (MIC) of spice extracts as another antibacterial activity was also determined. MIC was considered to be the lowest concentration that inhibits growth after incubation. The liquid dilution method has been tried as described in CLSI standards (CLSI, 2003; CLSI, 2006). The final concentrations of extracts were adjusted to $13000,6500,3250,1625,812.5$, and $406.25 \mu \mathrm{g} / \mathrm{ml}$.

\subsection{Determination of Non-Enzymatic Antioxidant}

\section{Activity}

Non-enzymatic antioxidant activity was determined using DPPH [2,2-Diphenyl-1-picrylhydrazyl] as a free radical. Stable DPPH was used to determine the free radical scavenging activities of the extracts. The extract $(0.1 \mathrm{ml})$ was added to 3.9 $\mathrm{ml}$ of $0.1 \mathrm{mM}$ methanol DPPH solution. After 30 minutes of incubation, the absorbance of the extract was measured at 515 $\mathrm{nm}$ using a spectrophotometer. While methanol DPPH solution was used as a control, methanol was used as a blind. Trolox was used as a reference antioxidant. DPPH was calculated using the scavenging capacity formula and given as (\%) (Brand-Williams et al., 1995).

\section{Results and Discussion}

In this study, antibacterial activity studies were conducted using the disk diffusion method reported by Kirby-Bauer (1966). The plant extracts $(150 \mathrm{mg} / \mathrm{ml})$ were tested by the disk diffusion method, and the cultures were incubated on Mueller-Hinton Agar plates for 24 hours at their own temperature. At the end of antimicrobial activity studies, methanol and aqueus extracts of Ribes nigrum (currants) showed effective antibacterial activity against Salmonella Typhimurium RSKK19. The antibacterial activities of other spice extracts against this bacterium have not been found. In another bacterium, Escherichia coli ATCC11229, only one extract showed effective activity. This is Nigella sativa ethanol extract $(8 \mathrm{~mm}) .2$ different spice extract showed antibacterial activity against Listeria monocytogenes ATCC7644. These are Mentha piperita $(7 \mathrm{~mm})$ and Origanum majorana $(7 \mathrm{~mm})$ spices, respectively. The antibacterial activities were not found in other spices extracts. 2 spices were effective against Candida albicans RSKK02029. While only ethanol extract of Nigella sativa $(8 \mathrm{~mm})$ was effective, Thymus serpyllum $(8 \mathrm{~mm})$ showed activity in both ethanol and methanol extracts. No antimicrobial activity was determined from either of the other 
spices studied. These are Coriandrum sativum and Crocus sativus (Table 1).

Table 1. Antimicrobial activities of spice extracts against food pathogens

\begin{tabular}{|c|c|c|c|c|c|}
\hline \multirow{2}{*}{$\begin{array}{l}\text { Plant } \\
(150 \mathrm{mg} / \mathrm{ml})\end{array}$} & \multirow{2}{*}{ Solvent } & \multicolumn{4}{|c|}{ Inhibition Zone Diameters (mm) } \\
\hline & & \multicolumn{4}{|c|}{ Microorganisms } \\
\hline \multirow[t]{2}{*}{ Mentha piperita } & Methanol & - & - & - & - \\
\hline & Aqueous & - & - & - & - \\
\hline \multirow{2}{*}{ Ribes nigrum } & Ethanol & - & - & - & - \\
\hline & Aqueous & 8 & - & - & - \\
\hline \multirow{3}{*}{ Nigella sativa } & Ethanol & - & 8 & - & 8 \\
\hline & Methanol & - & - & - & - \\
\hline & Aqueous & - & - & - & - \\
\hline \multirow{2}{*}{$\begin{array}{l}\text { Origanum } \\
\text { majorana }\end{array}$} & Ethanol & - & - & 7 & - \\
\hline & Methanol & - & - & - & - \\
\hline $\begin{array}{l}\text { Thymus } \\
\text { serpyllum }\end{array}$ & Aqueous & - & - & - & - \\
\hline \multirow{3}{*}{$\begin{array}{l}\text { Coriandrum } \\
\text { sativum }\end{array}$} & Ethanol & - & - & - & - \\
\hline & Methanol & - & - & - & - \\
\hline & Aqueous & - & - & - & - \\
\hline \multirow{3}{*}{ Crocus sativus } & Ethanol & - & - & - & - \\
\hline & Methanol & - & - & - & - \\
\hline & Aqueous & - & - & - & - \\
\hline
\end{tabular}

\section{(-): No Zone}

In this study, 3 reference antibiotics were used as the positive control. These are penicillin $(10 \mu \mathrm{g})$, chloramphenicol $(30 \mu \mathrm{g})$, and nystatin $(100 \mu \mathrm{g})$. Chloramphenicol strongly inhibited the growth of Salmonella and Listeria. Nystatin, on the other hand, weakly inhibited the growth of Candida albicans (Table 2).

Table 2. Effects of reference antibiotics and solvents against food pathogens

\begin{tabular}{|c|c|c|c|c|c|c|}
\hline \multirow[b]{3}{*}{ Microorganisms } & \multicolumn{6}{|c|}{ Inhibition Zone Diameters (mm) } \\
\hline & \multicolumn{3}{|c|}{ Antibiotics } & \multicolumn{3}{|c|}{ Solvent } \\
\hline & $\begin{array}{l}\text { Penicillin } \\
(10 \mu \mathrm{g})\end{array}$ & Chloramphenicol (30 $\mu \mathrm{g})$ & Nystatin $(100 \mu \mathrm{g})$ & $\mathbf{E}$ & $\mathbf{M}$ & $\mathbf{A}$ \\
\hline Salmonella Typhimurium RSKK19 & 9 & 22 & NT & - & - & - \\
\hline Escherichia coli ATCC11229 & 8 & 21 & NT & - & - & - \\
\hline Listeria monocytogenes ATCC7644 & 7 & 22 & NT & - & - & - \\
\hline Candida albicans RSKK02029 & NT & NT & 7 & - & - & - \\
\hline
\end{tabular}

NT: Not Tested; E: Ethanol; M: Methanol; A: Aqueous; (-): No İnhibition

Another antimicrobial activity test in this study is MIC. It contains MIC values of different solvents of different spices provided by the broth dilution method. MIC test was not applied to Coriandrum sativum and Crocus sativus, which did not show antimicrobial activity. According to the results obtained from this study, the lowest MIC value was determined from Origanum majorana and Mentha piperita $(3250 \mu \mathrm{g} / \mathrm{ml})$ against Listeria monocytogenes ATCC7644, and Candida albicans RSKK02029, the lowest MIC value $(3250 \mu \mathrm{g} / \mathrm{ml})$ was determined from Thymus serpyllum extract (Table 3 ). 
Table 3. Minimum inhibitory concentrations of spice extracts $(\mu \mathrm{g} / \mathrm{ml})$

\begin{tabular}{l|l|c|c|c|c}
\hline \multicolumn{1}{c|}{ Extract } & Solvent & $\begin{array}{c}\text { Salmonella } \\
\text { Typhimurium RSKK19 }\end{array}$ & $\begin{array}{c}\text { Escherichia coli } \\
\text { ATCC11229 }\end{array}$ & $\begin{array}{c}\text { Listeria monocytogenes } \\
\text { ATCC7644 }\end{array}$ & $\begin{array}{c}\text { Candida albicans } \\
\text { RSKK02029 }\end{array}$ \\
\hline $\begin{array}{l}\text { Mentha } \\
\text { piperita }\end{array}$ & Ethanol & $\mathrm{nt}$ & $\mathrm{nt}$ & 3250 & $\mathrm{nt}$ \\
\hline \multirow{2}{*}{$\begin{array}{l}\text { Ribes nigrum } \\
\text { Nigella sativa }\end{array}$} & Methanol & 6500 & $\mathrm{nt}$ & $\mathrm{nt}$ & $\mathrm{nt}$ \\
\cline { 2 - 6 } $\begin{array}{l}\text { Eriganum } \\
\text { majorana }\end{array}$ & Ethanol & - & $\mathrm{nt}$ & $\mathrm{nt}$ & $\mathrm{nt}$ \\
\hline $\begin{array}{l}\text { Thymus } \\
\text { serpyllum }\end{array}$ & Ethanol & $\mathrm{nt}$ & $\mathrm{nt}$ & 3250 & $\mathrm{nt}$ \\
\hline & Methanol & $\mathrm{nt}$ & $\mathrm{nt}$ & $\mathrm{nt}$ & 3250 \\
\hline
\end{tabular}

(nt): Not Tested ; (-): No minimum concentration of inhibitors was observed at concentrations up to $13000 \mu \mathrm{g} / \mathrm{ml}$.

Antioxidant activity studies have been done on ethanol, methanol, and aqueous extracts of all spice extracts, and the obtained data are given in Table 4. According to the results of this study; the highest antioxidant activities were determined from the aqueous extract of Mentha piperita (\%83.8), methanol extract of Nigella sativa (\%84), methanol extract of Ribes nigrum (\% 83.3), methanol extract of Crocus sativus (\%82.8), methanol extract of Thymus serpyllum (\%60.8), the aqueous extract of Origanum majorana (\%78.4) and from the methanol extract of Coriandrum sativum (\%82.4). The antioxidant activities of spices have been determined from highest to lowest, as Nigella $>$ Mentha $>$ Ribes $>$ Crocus $>$ Coriandrum $>$ Origanum $>$ Thymus. Another striking point is that high antioxidant activities were obtained from methanol extracts when organic solvents were compared (Table 4).

Table 4. DPPH radical scavenging activities of different spice extracts $(150 \mathrm{mg} / \mathrm{ml})$

\begin{tabular}{|c|c|c|c|c|c|c|}
\hline \multirow{2}{*}{ Plant } & \multicolumn{2}{|l|}{ EE } & \multicolumn{2}{|l|}{ ME } & \multicolumn{2}{|l|}{ AE } \\
\hline & Scavenging (\%) & TE & Scavenging (\%) & TE & Scavenging (\%) & TE \\
\hline Mentha piperita & 1.64 & 1.67 & 51.9 & 1.78 & 83.8 & 2.33 \\
\hline Nigella sativa & 63.3 & 2.27 & 84.1 & 2.35 & 55.3 & 1.79 \\
\hline Ribes nigrum & 29.5 & 1.95 & 83.3 & 2.34 & 63.8 & 1.96 \\
\hline Crocus sativus & 72.8 & 2.37 & 82.8 & 2.33 & 44.1 & 1.59 \\
\hline Thymus serpyllum & 52.8 & 2.17 & 60.8 & 1.95 & 54.1 & 1.77 \\
\hline
\end{tabular}

TE: Trolox Equivalent (mM trolox/g DW); DW: Dry weight; EE: Ethanol extract; ME: Methanol extract; AE: Aqueous extract

Today, consumers prefer more natural foods, the effects of toxic synthetic foodstuffs, and the increasing resistance of pathogenic microorganisms to antibiotics is pointed out as a good source of food preservatives of natural compounds isolated from plants (Smith et al., 2001; Burt, 2004; Peschel et al. , 2006). Medicinal and aromatic plants provide an adequate source of biologically active compounds, many of which are used in the development of new pharmacological (Palombo, 2011).

In the current study, extracts of spices in different solvents were tested against 4 food pathogens. Antimicrobial activity was compared with standard antibiotics (Tables 1 and 2). In this study, various extracts of different spices were tested against test microorganisms, and their antimicrobial potentials were determined by inhibition zone diameter and MIC.

In this study, Nigella sativa shown activity against Escherichia coli and Candida albicans (Table 1). In a study, the inhibitory effects of sage, rosemary, black seed, cumin, clove, thyme, and their basic components were analyzed. In the study, it was determined that various essential oils prevent microbial growth even at a $0.25-12 \mathrm{mg} / \mathrm{ml}$ ratio, and essential oils and their basic components are more effective on Gram-negative bacteria than Gram-positive bacteria (Farag et al., 1989). These studies show a similarity to our results. Besides, another study on the effectiveness of seven spices (cumin, thyme, laurel, myrtle leaf, e-ISSN: 2148-2683 immortelle, marjoram, laurel) extracts on the growth of Escherichia coli $0157: \mathrm{H7}$ was reported that thyme and marjoram show higher antimicrobial activity than other spice varieties (Sagdiç et al., 2003). Khalid et al., (2011) in their study, reported that Nigella showed antibacterial activity against the 5 test bacteria. Our results differ compared to those obtained from this literature. These differences may be due to environmental and genetic factors, as well as different chemotypes and nutritional status of plants and it is possible to be affected by the change of oil composition depending on other factors (Özcan and Chalchat, 2002). Arıdoğan et al. (2002) reported that Mentha piperita was ineffective against Escherichia coli. This study supports our results. Arıdoğan et al. (2002) reported that Origanum onite essential oil shows a $25 \mathrm{~mm}$ inhibition zone against Escherichia coli. As a result of our studies, no antibacterial effect of Origanum majorana extracts against Escherichia coli was detected (Table 1). In our study, the antimicrobial activity of Ribes nigrum extracts against Escherichia coli and Candida albicans was not detected (Table 1). Similarly, Rauha et al. (2000) achieved the same result in their study.

In this study, the authors were determined that Origanum majorana extract show activity $(7 \mathrm{~mm})$ against Listeria monocytogenes (Table 1). Based on the information in the literature, it is reported that Origanum majorana may be useful as an antimicrobial agent, and this oil has great potential in 
industrial applications (Ezzeddine et al., 2001). Ting and Deibel (1992) investigated the effect of some spices on the growth of Listeria monocytogenes, they found that the minimum inhibition concentration of cloves or dianthus, and wild marjoram was 0.5 $0.7 \% \mathrm{a} / \mathrm{h}$. They were the two most effective spices. In a part of the study, the effects of cloves, wild marjoram, and sage tea at $4^{\circ} \mathrm{C}$ and $24^{\circ} \mathrm{C}$ on the survival and growth of Listeria monocytogenes (Scott A) were investigated. At the end of this study, whereas clove showed bactericide, wild marjoram showed the bacteriostatic effect. These studies from the literature support our results.

According to the results obtained from the Mentha piperita studies, it was determined that ethanol extracts have effective antibacterial activity against the Listeria $(7 \mathrm{~mm})$, and the MIC value was determined as $3250 \mu \mathrm{g} / \mathrm{ml}$ (Tables 1 and 3). However, İşcan et al. (2002) reported a MIC value lower than the MIC value in this study. The reason for the difference between studies may be related to the fact that the mint used in the trials was collected from different regions and the menthol contents were different from each other (Özcan and Chalchat, 2002).

Coriandrum sativum (coriander) and Crocus sativus (saffron) extract were determined to not show antimicrobial activities against test microorganisms (Table 1). Soureshjan and Heidari (2014) reported that saffron did not show activity against Escherichia coli in their study. These results support our work. Acar et al. (2010) reported that different Crocus species have antimicrobial activity in their study. Asgarpanah et al. (2013) reported that Crocus sativus has antibacterial activity against Salmonella and Escherichia coli. Jastaniah (2014) reported that these plant extracts show antibacterial activity against Escherichia coli and Salmonella. Antimicrobial activity alters highly dependent on spice or plant species, test environment, and microorganisms (Indu and Hatha, 2006). As a result of our study, we were determined that Thymus serpyllum showed anticandidal activity, and an $8 \mathrm{~mm}$ inhibition zone was determined by ethanol and methanol extracts (Table 1). These results support our work. In this study, the MIC value against Candida albicans was determined as 3250 and $13000 \mu \mathrm{g} / \mathrm{ml}$. Nikolic et al. (2014) reported the MIC value as $2 \mu \mathrm{g} / \mathrm{ml}$ in their study.

The screening of plant extracts with the DPPH freescavenging method to determine antioxidant activities is an effective selection method. The plant extracts can be rich in flavonoids for radical scavenging activity. The free radical scavenging and antioxidant activities of most medicinal plants have been reported in the literature. These properties of medicinal plants are effective against cancer, tissue inflammation, and cardiovascular diseases (Cai et al., 2004).

In our antioxidant activity studies, antioxidant activities of different solvents were scanned for all spices, and different results were obtained according to plants, and high antioxidant activities were determined (Table 4). The high antioxidant activities are associated with the number of phenolic ingredients and total flavonoids in the extracts. Flavonoids are known as powerful radical scavengers (Robak and Gryglewski, 1988). Burits and Bucar (2000) reported that spice has antioxidant activity and essential oil composition in their study with Nigella sativa. Another study reported that rosmarinic acid content was very high in Oregano extracts (Chen and Ho, 1997). In a study with Mentha, strong radical scavenging compounds have been reported, such as monoterpene ketones and 1,8-cineole (menthone and iso menthone) (Mimica-Dukic et al., 2003). Zheng and Wang (2001) and İşcan et al. (2002) reported that there are phenolic compounds in the structure of the essential oils of Mentha piperita. Darughe et al. (2012) reported that Coriandrum sativum essential oils contain phenolic compounds in their chemical composition. Wong and Kitts (2006) reported in their study with coriander, the antioxidant activity of root methanol extracts as $44 \%$, however, the result obtained from our studies was $82.35 \%$ and higher. The essential oil composition of Coriandrum sativum leaves is monoterpenes, aldehydes, alcohols, and alkanes as reported (Matasyoh et al., 2009). Oussalah et al. (2007) reported that Coriandrum sativum had linalool in its essential oil, terpene, terpinene, and thymol in the essential oil of Origanum majorana, and Thymus serpyllum's oil had cymene and carvacrol. These results obtained from the literature support our studies. Ramadan et al. (2012) reported that ethanolic extracts $(20,40,60,80$, and $100 \mathrm{mg} / \mathrm{ml})$ of Crocus sativus at different concentrations did not show antioxidant activity, while Ferrara et al. (2014) studies showed 14-16\% antioxidant activity. As a result of our studies, high antioxidant activity was found (Table 4). Acar et al. (2010) reported in their study that methanol extracts of different Crocus species showed high antioxidant activity. Okmen et al. (2016) reported that ethanol extract of Crocus leaves had $84 \%$ DPPH scavenging activity. These studies support our results. The reasons for this difference, as reported by Raina et al. (1996) and Maggi et al. (2009), differences in harvest time, processing temperature, storage, and packaging may enormously affect the quality of the end product. According to Fogden and Neuberger (2003), active ingredients of plants are affected by location and quality control, including harvest season, preparation methods, plant species, altitude, and climate.

In this study, the radical scavenging effect of Thymus serpyllum aqueous extract was determined as $60.8 \%$ (Table 4). Mata et al. (2007) studied the essential oil composition of the plant and found the terpenoids that they thought were responsible for antioxidant activity. Sokmen et al. (2004) studied the essential oil composition of Thymus spathulifolius, and gave the proportions of phenolic compounds, also demonstrating the presence of radical scavenging and antimicrobial activities. Adzet et al. (1988), in their study, reported the presence of polyphenols and methoxylated flavonoids in the structure of the Thymus. Kulisic et al. (2005) in their study, determined the essential oil composition of Thymus vulgaris and Thymus serpyllum and recorded DPPH scavenging activity as $38 \%$ in Thymus vulgaris and $30 \%$ in Thymus serpyllum. According to the literature, researchers were studied with Thymus eigii, which has phenolic monoterpenes thymol and carvacrol (Tepe et al, 2004). These studies support our results.

\section{Conclusions and Recommendations}

The results of the current study have shown that different spices have antimicrobial properties. Researchers expect that the development of natural antimicrobials to be help reduce the negative effects of synthetic drugs. Our results support the use of these herbs in traditional medicine, and some of these herbs show that they havcole good antibacterial and antifungal compounds, so they can be used as antibacterial and antifungal agents in the research of new drugs. The antioxidant activities were determined in all of the spices extracts used in the study 
and most of these activities were obtained from methanol extracts.

According to this study results, methanol is the most effective solvent for antioxidant compounds. The extracts of spices can be useful as an antioxidant protective system for the human body against oxidative stress. More studies are needed to investigate the bioactive compounds of spices. It is necessary to determine and characterize the fractions of bioactive compounds.

\section{Acknowledgement}

This work was supported by Mugla Sitki Kocman University Scientific Research Project (BAP-14/054). The authors thank Mugla Sitki Kocman University.

\section{References}

Abdel-Fattah, A. F. M., Matsumoto, K., \& Watanabe, H. (2000). Antinociceptive effects of Nigella sativa oil and its major component, thymoquinone, in mice. European Journal of Pharmacology, 400(1), 89-97.

Abdel-Massih, R. M, Fares, R., Bazzi, S., El-Chami, N., \& Baydoun, E. (2010). The apoptotic and antiproliferative activity of Origanum majorana extracts on human leukemic cell line. Leuk. Res., 34,1052-1056.

Acar, G., Dogan, N. M., Duru, M. E., \& Kivrak, I. (2010). Phenolic profiles, antimicrobial and antioxidant activity of the various extracts of Crocus species in Anatolia. African Journal of Microbiology Research, 4(11), 1154-1161.

Adzet, T., Vila, R., \& Canigueral, S. (1988). Chromatographic analysis of polyphenols of some Iberian Thymus. Journal of Ethnopharmacology, 24(2-3), 147-154.

Akgül, A. (1993). Baharat bilimi ve teknolojisi. Gıda Teknolojisi Derneği Yayınlarl, 15, 111-113.

Andoğan, B. C., Baydar, H., Kaya, S., Demirci, M., Özbaşar, D., \& Mumcu, E. (2002). Antimicrobial activity and chemical composition of some essential oils. Archives of Pharmacal Research, 25(6), 860-864.

Asgarpanah, J., Darabi-Mahboub, E., Mahboubi, A., Mehrab, R., \& Hakemivala, M. (2013). In-vitro evaluation of Crocus sativus L. petals and stamens as natural antibacterial agents against food-borne bacterial strains. Iranian Journal of Pharmaceutical Sciences, 9(4), 69-82.

Badary, O. A. (1999). Thymoquinone attenuates ifosfamideinduced Fanconi syndrome in rats and enhances its antitumor activity in mice. Journal of Ethnopharmacology, 67(2), 135142.

Badary, O. A., Abdel-Naim, A. B., Abdel-Wahab, M. H., \& Hamada, F. M. (2000). The influence of thymoquinone on doxorubicin-induced hyperlipidemic nephropathy in rats. Toxicology, 143(3), 219-226.

Bauer, A.W, Kirby W.M, Sherris J.C, \& Turck M. (1966). Am. J. Clin. Path, 45,493.

Baytop, T. (1999). Türkiye'de bitkiler ile tedavi: geçmişte ve bugün. Nobel Tıp Kitabevleri.

Brand-Williams, W., Cuvelier, M. E., \& Berset, C. L. W. T. (1995). Use of a free radical method to evaluate antioxidant activity. LWT-Food science and Technology, 28(1), 25-30.

Burits, M., \& Bucar, F. (2000). Antioxidant activity of Nigella sativa essential oil. Phytotherapy Research, 14(5), 323-328.
Burt, S. (2004). Essential oils: their antibacterial properties and potential applications in foods-a review. International Journal of Food Microbiology, 94(3), 223-253.

Cai, Y., Luo, Q., Sun, M., \& Corke, H. (2004). Antioxidant activity and phenolic compounds of 112 traditional Chinese medicinal plants associated with anticancer. Life Sciences, 74(17), 2157-2184.

Chen, J. H. \& Ho, C. T. (1997). Antioxidant activities of caffeic acid and its related hydroxycinnamic acid compounds. $J$. Agric. Food Chem., 45, 2374-2378.

CLSI (Clinical and Laboratory Standards Institute). (2003). Methods for Dilution Antimicrobial Susceptibility Test for Bacteria that Grow Aerobically; Approved Standard M7-A 6th edn. National Committee for Clinical Laboratory Standards, Wayne, Philadelphia.

CLSI (Clinical and Laboratory Standards Institute). (2006). Performance Standards for Antimicrobial Susceptibility Testing. 16th Informational Supplement M100-S16. National Committee for Clinical Laboratory Standards, Wayne, Philadelphia.

Darughe, F., Barzegar, M., \& Sahari, M. A. (2012). Antioxidant and antifungal activity of Coriander (Coriandrum sativum L.) essential oil in cake. International Food Research Journal, 19(3), 1253-1260.

Davis, P. H., \& Tan, K. (Eds.). (1988). Flora of Turkey and the Aegean islands. Edinburgh University Press.

De Vincenzi, M., Mancini, E., \& Dessi, M. R. (1997). Monographs on botanical flavouring substances used in foods. Part VI. Fitoterapia (Milano), 68(1), 49-61.

Declume, C. (1989). Anti-inflammatory evaluation op a hydroalcoholic extract op black currant leaves (Ribes nigrum). Journal of Ethnopharmacology, 27(1-2), 91-98.

Dvaranauskaite, A., Venskutonis, P. R., Raynaud, C., Talou, T., Viškelis, P., \& Dambrauskiene, E. (2008). Characterization of steam volatiles in the essential oil of black currant buds and the antioxidant properties of different bud extracts. Journal of Agricultural and Food Chemistry, 56(9), 32793286.

Dvaranauskaite, A., Venskutonis, P. R., Raynaud, C., Talou, T., Viškelis, P., \& Sasnauskas, A. (2009). Variations in the essential oil composition in buds of six blackcurrant (Ribes nigrum L.) cultivars at various development phases. Food Chemistry, 114(2), 671-679.

Escribano, J., Alonso, G. L., Coca-Prados, M., \& Fernández, J. A. (1996). Crocin, safranal and picrocrocin from saffron (Crocus sativus L.) inhibit the growth of human cancer cells in vitro. Cancer Letters, 100(1-2), 23-30.

Ezzeddine, N.B, Abdelkafi, M.M, Ben, Aissa, R, \& Chaabouni M. M. (2001). Antibacterial screening of (Origanum majorana L.), oil from Tunisia. Journal of Essential Oil Research, 13, 295-297.

Facciola S. (1998). Cornucopia II: a source book of edible plants. Vista: Kampong Publications (HSA Library).

Farag, R. S., Daw, Z. Y., Hewedi, F. M., \& El-Baroty, G. S. A. (1989). Antimicrobial activity of some Egyptian spice essential oils. Journal of Food Protection, 52(9), 665-667.

Ferrara, L., Naviglio, D., \& Gallo, M. (2014). Extraction of bioactive compounds of saffron (Crocus sativus L.) by ultrasound assisted extraction (UAE) and by rapid solid- 
liquid dynamic extraction (RSLDE). European Scientific Journal, 10(3),1-13.

Fogden, E., \& Neuberger, J. (2003). Alternative medicines and the liver. Liver International, 23(4), 213-220.

Garbacki, N., Kinet, M., Nusgens, B., Desmecht, D., \& Damas, J. (2005). Proanthocyanidins, from Ribes nigrum leaves, reduce endothelial adhesion molecules ICAM-1 and VCAM-1. Journal of Inflammation, 2(1), 1-12.

Gürsoy, O.V, Gürsoy, U.K. (2004). Anadolu'da diş ve dişeti ile ilgili hastalıkların tedavisinde halk arasında yaygın olarak kullanılan bitkiler, kullanım şekilleri ve bitkisel özellikleri. Cumhuriyet Üniversitesi Diş Hekimliği Fakültesi Dergisi, Sivas, 7(1), 64-67.

Halawani, E. (2009). Antibacterial activity of thymoquinone and thymohydroquinone of Nigella sativa $\mathrm{L}$. and their interaction with some antibiotics, Advances in Biological Research, 3(56), 148-152.

Hosseinzadeh, H., Khosravan V. (2002a). Anticonvulsant effects of aqueous and ethanolic extracts of Crocus sativus L. stigmas in mice, Archieve of Iranian Medicine, 5, 44-47.

Hosseinzadeh, H., Karimi G.H, Niapoor M. (2004). Antidepressant effects of Crocus sativus stigma extracts and its constituents, crocin and safranal, in mice, Acta Horticulturae (ISHS), 650, 435-445.

Hosseinzadeh, H., Younesi H.M. 2002b. Antinociceptive and antiinflammatory effects of Crocus sativus L. stigma and petal extracts in mice, BMC Pharmacology, 2, 1-8.

Indu, M.N., Hatha A.A.M., Abirosh C., Harsha U., Vivekanandan, G. (2006). Antimicrobial activity of some of the South-Indian spices against serotypesof Escherichia coli, Salmonella, Listeria monocytogenes and Aeromonas hydrophila. Brazilian Journal of Microbiology, 37:153-158. ISSN 1517-8382153.

İşcan, G., Kirimer, N., Kürkcüoğlu, M., Başer, H. C., \& Demirci, F. (2002). Antimicrobial screening of Mentha piperita essential oils. Journal of Agricultural and Food Chemistry, 50(14), 3943-3946.

Jastaniah, S. D. (2014). The antimicrobial activity of some plant extracts, commonly used by Saudi people, against multidrug resistant bacteria. Life Sci J, 11(8), 78-84.

Kanter, M., Demir, H., Karakaya, C., \& Ozbek, H. (2005). Gastroprotective activity of Nigella sativa $\mathrm{L}$ oil and its constituent, thymoquinone against acute alcohol-induced gastric mucosal injury in rats. World Journal of Gastroenterology: WJG, 11(42), 6662.

Kaseb, A. O., Chinnakannu, K., Chen, D., Sivanandam, A., Tejwani, S., Menon, M., Dou, Q. P. \& Reddy, G. P. V. (2007). Androgen receptor-and E2F-1-targeted thymoquinone therapy for hormone-refractory prostate cancer. Cancer Research, 67(16), 7782-7788.

Khalid, A., Rehman, U. U., Sethi, A., Khilji, S., Fatima, U., Khan, M. I., Waqas M.K., Saqib Q.N., Asad M. H. H. B, Farzana K., Mahmood, S., Waseem A., Ismail T., and Murtaza G. (2011). Antimicrobial activity analysis of extracts of Acacia modesta, Artimisia absinthium, Nigella sativa and Saussurea lappa against Gram positive and Gram negative microorganisms. African Journal of Biotechnology, 10(22), 4574-4580.

Kiran, S. R., Devi, P. S., \& Reddy, K. J. (2008). Evaluation of in vitro antimicrobial activity of leaf and stem essential oils of Chloroxylon swietenia DC. World Journal of Microbiology and Biotechnology, 24(9), 1909-1914.
Koidis, P., Grigoriadis, S., \& Batzios, C. (1996). Behaviour of Campylobacter jejuni in broth stored at $4^{\circ} \mathrm{C}$, with different concentration of spices (garlic, onion, black pepper, oregano). Archiv für Lebensmittelhygiene, 47(4), 93-95.

Kulisic, T., Radonic, A., \& Milos, M. (2005). Antioxidant properties of thyme (Thymus vulgaris L.) and wild thyme (Thymus serpyllum L.) essential oils. Italian Journal of Food Science, 17(3), 315.

Leung, A. Y. (1980). Encyclopedia of common natural ingredients used in food, drugs, and cosmetics. Wiley.

Maggi, L., Carmona, M., Del Campo, C. P., Kanakis, C. D., Anastasaki, E., Tarantilis, P. A., Polissiou, M G., Alonso, G. L. (2009). Worldwide market screening of saffron volatile composition. Journal of the Science of Food and Agriculture, 89(11), 1950-1954.

Martinez-Tome, M., Jimenez, A. M., Ruggieri, S., Frega, N., Strabbioli, R., \& Murcia, M. A. (2001). Antioxidant properties of Mediterranean spices compared with common food additives. Journal of Food Protection, 64(9), 14121419.

Mata, A. T., Proença, C., Ferreira, A. R., Serralheiro, M. L. M., Nogueira, J. M. F., \& Araújo, M. E. M. (2007). Antioxidant and antiacetylcholinesterase activities of five plants used as Portuguese food spices. Food Chemistry, 103(3), 778-786.

Matasyoh, J. C., Maiyo, Z. C., Ngure, R. M., \& Chepkorir, R. (2009). Chemical composition and antimicrobial activity of the essential oil of Coriandrum sativum. Food Chemistry, 113(2), 526-529.

Mimica-Dukić, N., Božin, B., Soković, M., Mihajlović, B., \& Matavulj, M. (2003). Antimicrobial and antioxidant activities of three Mentha species essential oils. Planta Medica, 69(05), 413-419.

Nascimento, G. G., Locatelli, J., Freitas, P. C., \& Silva, G. L. (2000). Antibacterial activity of plant extracts and phytochemicals on antibiotic-resistant bacteria. Brazilian Journal of Microbiology, 31(4), 247-256.

Nikolić, M., Glamočlija, J., Ferreira, I. C., Calhelha, R. C., Fernandes, Â., Marković, T., Marković, D., Giweli, A. \& Soković, M. (2014). Chemical composition, antimicrobial, antioxidant and antitumor activity of Thymus serpyllum L., Thymus algeriensis Boiss. and Reut and Thymus vulgaris L. essential oils. Industrial Crops and Products, 52, 183-190.

Novak, J., Bitsch, C., Pank, F., Langbehn, J., \& Franz, C. M. (2002). Distribution of the cis-sabinene hydrate acetatechemotype in accessions of marjoram (Origanum majorana L.). Euphytica, 127(1), 69-74.

Okmen, G., Kardas, S., Bayrak, B., Arslan, A., \& Cakar, H. (2016). The antibacterial activities of Crocus sativus against mastitis pathogens and its antioxidant activities. WJPPS, 5(3), 146-156.

Oprea, E., Rădulescu, V., Balotescu, C., Lazar, V., Bucur, M., Mladin, P., \& Farcasanu, I. C. (2008). Chemical and biological studies of Ribes nigrum L. buds essential oil. Biofactors, 34(1), 3-12.

Oussalah, M., Caillet, S., Saucier, L., \& Lacroix, M. (2006). Antimicrobial effects of selected plant essential oils on the growth of a Pseudomonas putida strain isolated from meat. Meat Science, 73(2), 236-244.

Oussalah, M., Caillet, S., Saucier, L., \& Lacroix, M. (2007). Inhibitory effects of selected plant essential oils on the growth of four pathogenic bacteria: E. coli O157: H7, Salmonella Typhimurium, Staphylococcus aureus and Listeria monocytogenes. Food Control, 18(5), 414-420. 
Özcan, M., \& Chalchat, J. C. (2002). Essential oil composition of Ocimum basilicum L. Czech J. Food Sci, 20(6), 223-8.

Palombo, E. A. (2009). Traditional medicinal plant extracts and natural products with activity against oral bacteria: potential application in the prevention and treatment of oral diseases. Evidence Based Complementary and AlternativeMedicine, 2011, 100.

Pamuk, A. (2008). Şifalı Bitkiler Ansiklopedisi. Pamuk Yayıncılik.

Peschel, W., Sánchez-Rabaneda, F., Diekmann, W., Plescher, A., Gartzía, I., Jiménez, D., Raventós, R. L., Buxaderas, S. \& Codina, C. (2006). An industrial approach in the search of natural antioxidants from vegetable and fruit wastes. Food Chemistry, 97(1), 137-150.

Picton, M. (2000). The book of magical herbs: herbal history, mystery, \& folklore. London: Barron's.

Raina, B. L., Agarwal, S. G., Bhatia, A. K., \& Gaur, G. S. (1996). Changes in Pigments and Volatiles of Saffron (Crocus sativus L) During Processing and Storage. Journal of the Science of Food and Agriculture, 71(1), 27-32.

Ramadan, A., Soliman, G., Mahmoud, S. S., Nofal, S. M., \& Abdel-Rahman, R. F. (2012). Evaluation of the safety and antioxidant activities of Crocus sativus and Propolis ethanolic extracts. Journal of Saudi Chemical Society, 16(1), 13-21.

Rauha, J. P., Remes, S., Heinonen, M., Hopia, A., Kähkönen, M., Kujala, T., Pihlaja, K., Vuorela, H., Vuorela, P. (2000). Antimicrobial effects of Finnish plant extracts containing flavonoids and other phenolic compounds. International Journal of Food Microbiology, 56(1), 3-12.

Rios, J. L., Recio, M. C., Giner, R. M., \& Manez, S. (1996). An update review of saffron and its active constituents. Phytotherapy Research, 10(3), 189-193.

Robak, J., \& Gryglewski, R. J. (1988). Flavonoids are scavengers of superoxide anions. Biochemical Pharmacology, 37(5), 837-841.

Sağdıç, O., Kuşçu, A., Özcan, M., \& Özçelik, S. (2002). Effects of Turkish spice extracts at various concentrations on the growth of Escherichia coli O157: H7. Food Microbiology, 19(5), 473-480.

Smith-Palmer, A., Stewart, J., \& Fyfe, L. (2001). The potential application of plant essential oils as natural food preservatives in soft cheese. Food Microbiology, 18(4), 463470.

Sokmen, A., Gulluce M., Akpulat H.A, Daferera D., Tepe B., Polissiou M., Sokmen M., Sahin F. (2004). The in vitro antimicrobial and antioxidant activities of the essential oils and methanol extracts of endemic Thymus spathulifolius, Food Control, 15, 627-634.

Soureshjan, E. H., \& Heidari, M. (2014). In vitro variation in antibacterial activity plant extracts on Glaucium elegans and saffron (Crocus sativus). Bangladesh Journal of Pharmacology, 9(3), 275-278.

Srivastava, J. P., Lambert, J., \& Vietmeyer, N. (1996). Medicinal plants: An expanding role in development. The World Bank.

Stefanakis, M. K., Anastasopoulos, E., Katerinopoulos, H. E., \& Makridis, P. (2014). Use of essential oils extracted from three Origanum species for disinfection of cultured rotifers (B rachionus plicatilis). Aquaculture Research, 45(11), 18611866.

Stević, T., Šavikin, K., Ristić, M., Zdunić, G., Janković, T., Krivokuća-Đokić, D., \& Vulić, T. (2010). Composition and antimicrobial activity of the essential oil of the leaves of black currant (Ribes nigrum L.) cultivar Čačanska crna. Journal of the Serbian Chemical Society, 75(1), 35-43.

Tabart, J., Kevers, C., Evers, D., \& Dommes, J. (2011). Ascorbic acid, phenolic acid, flavonoid, and carotenoid profiles of selected extracts from Ribes nigrum. Journal of Agricultural and Food Chemistry, 59(9), 4763-4770.

Tabart, J., Kevers, C., Pincemail, J., Defraigne, J. O., \& Dommes, J. (2006). Antioxidant capacity of black currant varies with organ, season, and cultivar. Journal of Agricultural and Food Chemistry, 54(17), 6271-6276.

Tabart, J., Kevers, C., Sipel, A., Pincemail, J., Defraigne, J. O., \& Dommes, J. (2007). Optimisation of extraction of phenolics and antioxidants from black currant leaves and buds and of stability during storage. Food Chemistry, 105(3), 1268-1275.

Tepe, B., Daferera, D., Sökmen, M., Polissiou, M., \& Sökmen, A. (2004). In vitro antimicrobial and antioxidant activities of the essential oils and various extracts of Thymus eigii M. Zohary et PH Davis. Journal of Agricultural and Food Chemistry, 52(5), 1132-1137.

Ting, W. E., \& Deibel, K. E. (1991). Sensitivity of Listeria monocytogenes to spices at two temperatures. Journal of Food Safety, 12(2), 129-137.

Üner, Y., Aksu, H., \& Ergün, Ö. (2000). Baharatın çeşitli mikroorganizmalar üzerine etkileri. Istanbul Üniversitesi Veteriner Fakültesi Dergisi, 26(1), 1-10.

Vagiri, M. R. (2012). Black currant (Ribes nigrum L.)-an insight into the crop. Introductory Paper at the Faculty of Landscape Planning, Horticulture and Agricultural Science (No. 2012: 2). Swedish University of Agricultural Sciences. pp1-58. ISSN 1654-3580.

Verma, S. K., \& Bordia, A. (1998). Antioxidant property of saffron in man. Indian Journal of Medical Sciences, 52(5), 205-207.

Wanner, M. J., Koomen, G. J., \& Dung, N. X. (1993). Thymoquinone from Eupatorium ayapana. Planta Medica, 59(01), 99-99.

WHO (World Health Organization). (2005). Food safety. WORLD Health Organization. Available From: www.who.int/mediacentre/factsheets/fs237/en/ [Accessed 28 November 2020].

WHO, 2008. Exposure assessment of microbiological hazards in food. World Health Organization. Available from: www. who.int/foodsafety/publications/micro/en/report.pdf [Accessed 28 November 2020].

Winterhalter, P., \& Straubinger, M. (2000). Saffron-renewed interest in an ancient spice. Food Reviews International, 16(1), 39-59.

Wong, P. Y., \& Kitts, D. D. (2006). Studies on the dual antioxidant and antibacterial properties of parsley (Petroselinum crispum) and cilantro (Coriandrum sativum) extracts. Food Chemistry, 97(3), 505-515.

Zheng, W., \& Wang, S. Y. (2001). Antioxidant activity and phenolic compounds in selected herbs. Journal of Agricultural and Food Chemistry, 49(11), 5165-5170. 